\section{p53, c-myc p62 and proliferating cell nuclear antigen (PCNA) expression in non-Hodgkin's lymphomas}

\author{
P Korkolopoulou, J Oates, C Kittas, J Crocker
}

\begin{abstract}
Aims-To investigate the immunohistochemical expression of p53 protein in non-Hodgkin's lymphomas (NHL) and its relation to that of $c-m y c$ p62 oncoprotein and proliferating cell nuclear antigen (PCNA).

Methods-Paraffin wax embedded tissue from 90 non-Hodgkin's lymphomas (72 B cell and $18 \mathrm{~T}$ cell) was stained immunohistochemically for p53 protein, c-myc p62 oncoprotein, and PCNA using the monoclonal antibodies DO7, c-myc 1-9 E10, and PC-10, respectively.

Results-Of the non-Hodgkin's lymphomas studied, 55 (61\%) stained positively for p53 protein. The proportion of positive cases increased from low grade through intermediate to high grade nonHodgkin's lymphoma and was higher in tumours of $T$ cell origin. The percentage of positive cells (labelling index or LI) was significantly lower in low grade nonHodgkin's lymphoma, but no difference was established between intermediate and high grade non-Hodgkin's lymphoma. In a large proportion of low grade non-Hodgkin's lymphoma the LI was below 1\%. c-myc p62 immunoreactivity was identified in all cases. A significant positive correlation was established between p53 LI and c-myc p62 LI $\left(r_{s}=0.453\right)$ as well as between p53 LI and PCNA LI $\left(r_{s}=0 \cdot 338\right)$.

Conclusions-p53 immunoreactivity was present in about half the cases of nonHodgkin's lymphoma and was related to the grade of malignancy and possibly to the $B$ or $T$ cell origin of the tumour. It was also associated with the proliferation state as expressed by PCNA LI and cmyc p62 expression, indicating that the expression of these three cell cyclerelated genes might be interrelated.
\end{abstract}

$(7$ Clin Pathol 1994;47:9-14)

The p53 gene, located on chromosome $17 \mathrm{p} 13$, encodes a nuclear phosphoprotein which seems to be a negative regulator of cell growth and division. ${ }^{1}$ Wild type p53 can suppress or inhibit the transformation of cells in culture by viral or cellular oncogenes, ${ }^{23}$ reduce or eliminate the tumorigenic potential of a cell line in culture, and arrest the cell cycle of a transformed cell at the $G_{1}$ phase. ${ }^{45}$ It is therefore regarded as a tumour suppressor gene or anti-oncogene. It has also been associated with apoptosis; its role is to hold a damaged cell in $G_{1}$ phase while DNA repair is taking place. Cells which try to oppose the $G_{1}$ block may end up by activating the suicide (apoptosis) pathway. ${ }^{6}$

Mutations in the p53 gene are turning out to be the most common genetic alterations in many human cancers. ${ }^{78}$ Such mutations, when occurring within the coding region of the gene, can convert normal p53 into a dominant oncogene. There is evidence that mutant p53 protein may exert its oncogenic effect in two ways. First, the mutant protein can form an inactive oligomeric complex with a wild type subunit (dominant loss of function mutation). Alternatively, mutant p53 may gain a new function which overcomes the negative regulation by small quantities of wild type protein (gain of function mutation).$^{9}$

Wild p53 protein has a short intracellular half-life of 15 minutes ${ }^{10}$; mutant p53 protein forms complexes with heat shock protein 70 in the cytoplasm and has a longer half-life of several hours. ${ }^{2}$ Therefore, it has been suggested that the immunohistochemical detection of $\mathrm{p} 53$ protein corresponds to a mutation and not to up-regulation of the wild type gene. ${ }^{11-13}$ There is some evidence from studies in acute myelogenous leukaemia, however, that prolongation of the half-life of the wild p53 protein, which facilitates its immunohistochemical detection, is not necessarily related to an underlying genetic mutation. This implies that changes occur in the posttranslational processing of the protein. ${ }^{14}$

Abnormal expression of p53 has been reported in cases of acute and chronic lymphoid leukaemia. ${ }^{15} \mathrm{CD} 30$ positive anaplastic lymphomas ${ }^{16}$ and in a variety of nonHodgkin's lymphomas. ${ }^{17-22}$

The human c-myc oncogene is considered to be another cell cycle related gene. It is induced during the transition from $G_{0}$ to $G_{1}$ phase. ${ }^{23}$ It is expressed in a wide range of tissues at a level correlated with cell proliferation. ${ }^{24} \mathrm{c}-m y c$ can act as a bivalent regulator, determining either cell proliferation or apoptosis. It may be associated in vivo with a high turnover state in which cell proliferation and apoptosis coexist. ${ }^{25}$ Experimentally induced 
p53, c-myc p62, and PCNA expression in non-Hodgkin's lymphomas

\begin{tabular}{|c|c|c|c|c|c|}
\hline & \multicolumn{3}{|c|}{ p53 immunostaining } & \multirow{2}{*}{$\frac{c-m y c p 62 L I}{m e a n(S D)}$} & \multirow{2}{*}{$\frac{P C N A L I}{\text { mean }(S D)}$} \\
\hline & negative & $L I<1 \%$ & $L I>1 \%$ & & \\
\hline \multicolumn{6}{|l|}{ B cell lymphomas } \\
\hline Low grade & & & $3 / 13$ & $17(13)$ & $9(9)$ \\
\hline $\begin{array}{l}\text { B-CLL } \\
\text { lymphocyte predominant immunocytoma }\end{array}$ & $8 / 13$ & $2 / 13$ & $3 / 13$ & $17(13)$ & \\
\hline $\begin{array}{l}\text { (lymphoplasmacytic/ } \\
\text { lymphoplasmacytoid subtype) }\end{array}$ & $2 / 2$ & $0 / 2$ & $0 / 2$ & $5(0)$ & $5(0)$ \\
\hline centrocytic lymphoma & $0 / 1$ & $1 / 1$ & $0 / 1$ & 5 & 20 \\
\hline $\begin{array}{l}\text { centroblastic-centrocytic } \\
\text { lymphoma }\end{array}$ & 111 & $4 / 11$ & $3 / 11$ & 20 (11) & 19(11) \\
\hline monocytoid lymphoma & $1 / 1$ & $0 / 1$ & $0 / 1$ & 5 & 10 \\
\hline plasmacytic lymphoma & $0 / 1$ & $1 / 1$ & $0 / 1$ & 5 & \\
\hline Total & $15 / 29$ & $8 / 29$ & $6 / 29$ & $16(12)$ & $15(15)$ \\
\hline \multicolumn{6}{|l|}{ Intermediate-grade } \\
\hline $\begin{array}{l}\text { centrocytic lymphoma } \\
\text { centroblastic-centrocytic }\end{array}$ & $2 / 2$ & $0 / 2$ & $0 / 2$ & $23(11)$ & $14(8)$ \\
\hline lymphoma & $6 / 12$ & $2 / 12$ & $4 / 12$ & $37(27)$ & $31(20)$ \\
\hline centroblastic lymphoma & $3 / 17$ & $3 / 17$ & $11 / 17$ & $41(21)$ & $60(23)$ \\
\hline $\begin{array}{l}\text { lymphocyte predominant immunocytoma } \\
\text { (polymorphic subtype) }\end{array}$ & $4 / 5$ & $1 / 5$ & $0 / 5$ & $41(10)$ & $8(4)$ \\
\hline Total & $15 / 36$ & $6 / 36$ & $15 / 36$ & $39(20)$ & $41(28)$ \\
\hline \multicolumn{6}{|l|}{ High grade } \\
\hline immunoblastic lymphoma & $1 / 3$ & $0 / 3$ & $2 / 3$ & $85(7)$ & $85(9)$ \\
\hline lymphoblastic lymphoma & $2 / 3$ & $0 / 3$ & $1 / 3$ & $62(24)$ & $53(31)$ \\
\hline plasmacytic lymphoma & $0 / 1$ & $1 / 1$ & $0 / 1$ & 25 & \\
\hline Total & $3 / 7$ & $1 / 7$ & $3 / 7$ & $67(27)$ & $61(33)$ \\
\hline \multicolumn{6}{|l|}{ T cell lymphomas } \\
\hline Low grade & $1 / 3$ & $1 / 3$ & $1 / 3$ & $20(13)$ & $14(18)$ \\
\hline Intermediate grade & $1 / 8$ & $4 / 8$ & $3 / 8$ & $14(15)$ & $26(12)$ \\
\hline High grade & $0 / 7$ & $1 / 7$ & $6 / 7$ & $56(18)$ & $66(16)$ \\
\hline Total & $2 / 18$ & $6 / 18$ & $10 / 18$ & $31(25)$ & $40(26)$ \\
\hline
\end{tabular}

LP = lymphocyte predominant.

lymphocyte stimulation causes an increase in c-myc expression followed by an increase in DNA and RNA synthesis. ${ }^{26} \mathrm{c}-m y c$ encodes two nuclear phosphoproteins, of which p62 constitutes its main protein product. ${ }^{27}$

The detection of c-myc expression in various tissues can be performed by means of molecular biology and immunohistochemical techniques. The latter are of value in studying the c-myc p62 distribution in neoplastic and reactive cells, a discrimination which is especially important in non-Hodgkin's lymphoma. ${ }^{28}$ Overexpression of $c-m y c$ has been reported in many haematopoietic neoplasms, including non-Hodgkin's lymphoma. ${ }^{21}$ 28-32 This may reflect either a structural genetic abnormality or merely an increased rate of cell proliferation-it may be a consequence rather than a cause of tumorigenesis. ${ }^{33}$

Proliferating cell nuclear antigen (PCNA) is a 36 kilodalton nuclear protein that acts as an auxiliary factor of DNA polymerase $\delta$ and is considered to be involved in the cellular replication machinery. ${ }^{34}{ }^{35}$ PCNA concentrations are maximally increased at the late $G_{1}$ and $S$ phases of the cell cycle and correlate directly with the rates of cellular proliferation and DNA synthesis. ${ }^{36} 37$ PCNA immunolocalisation in paraffin wax sections has been used as an index of cell proliferation in malignant lymphomas. 323839

\section{Methods}

Ninety cases of non-Hodgkin's lymphoma coming from the files of the pathology departments of Athens School of Medicine and Tzanion Hospital (Piraeus) were examined. Diagnosis was made on the basis of routine histology and immunohistochemical tests. Seventy-two cases were diagnosed as B cell and 18 as $\mathrm{T}$ cell lymphomas. All cases were classified into three grades of malignancy according to the Working Formulation ${ }^{40}$ (table).

All specimens had been fixed in $10 \%$ formalin and routinely processed for paraffin wax embedding. Sections were cut at $3 \mu \mathrm{m}$ and mounted on Vectabond treated glass slides. The slides were dried at $37^{\circ} \mathrm{C}$ for at least 24 hours and then stained immunohistochemically for $\mathrm{p} 53$ protein using the monoclonal antibody DO7 (Dakopatts, High Wycombe, England), for c-myc p62 protein with c-myc 1-9 E10 (kindly provided by Professor D Spandidos), and for PCNA with PC-10 (Dakopatts, High Wycombe, England). DO7 recognises an epitope in the N-terminus of the human p53 protein between amino acids 35 to 45 . It reacts with both wild and mutant types of p53 protein. For immunostaining with the DO7 antibody the three-step avidin-biotin technique (Vecta-stain Elite PK6102, Vector) was used. The antibody was diluted 1 in 40 in phosphate buffered saline (PBS) (pH 7.4). c-myc 1-9 E10 was used at a dilution of 1 in 80 , as described before. ${ }^{31}$ PC-10 was diluted 1 in 150 with overnight incubation according to the procedure described by Hall et al. ${ }^{41}$

Staining was assessed blind (without knowing the histological diagnosis) by one observer. Positive non-neoplastic cells or cells showing only cytoplasmic staining were not taken into account. In each case nuclei from about 1000 tumour cells (from 10 high power fields) were counted and LI was calculated as the percentage of positive nuclei. Although the intensity of staining varied, all identifiable nuclear staining was recorded as positive. In cases with patchy staining, areas containing 
Figure 1 (A) DO7 immunostaining in a low grade lymphoma $(B$ chronic lymphocytic leukaemia). Sporadic positive cells are seen. (B) DO7 immunostaining in an intermediate grade $T$ cell lymphoma. Several positive cells are seen.

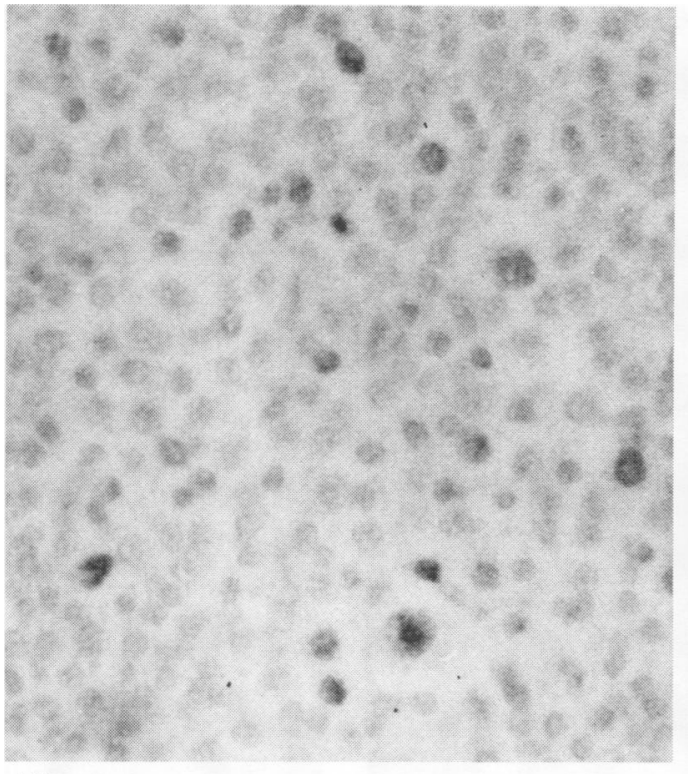

(A)

the highest and lowest number of positive cells were selected and the percentages were averaged to give the LI.

The results were evaluated statistically using Wilcoxon's rank sum test, the $\chi^{2}$ test, and Spearman's rank correlation coefficient.

\section{Results}

Of the 90 non-Hodgkin's lymphoma cases studied $55(61 \%)$ stained positively for p 53 protein. p53 immunoreactivity was clearly evident as granular nuclear staining and was confined to neoplastic cells alone (figs 1 and 2). In many cases a patchy distribution of positive cells throughout the tumour was observed. A characteristic pattern of staining was noted in cases of low grade lymphocytic lymphoma (B chronic lymphocytic leukaemia-B CLL)

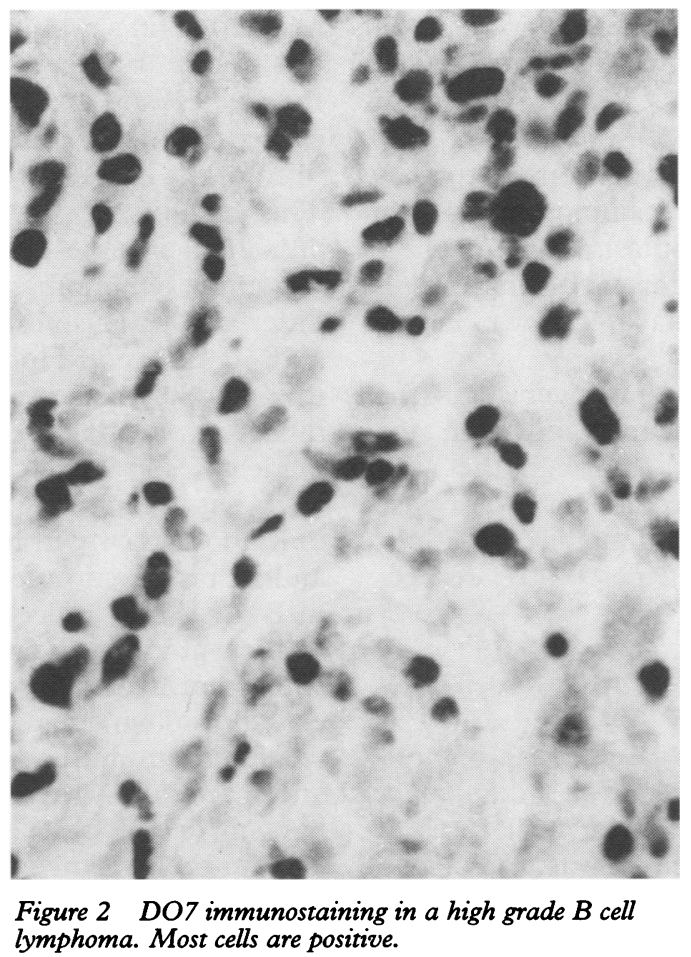

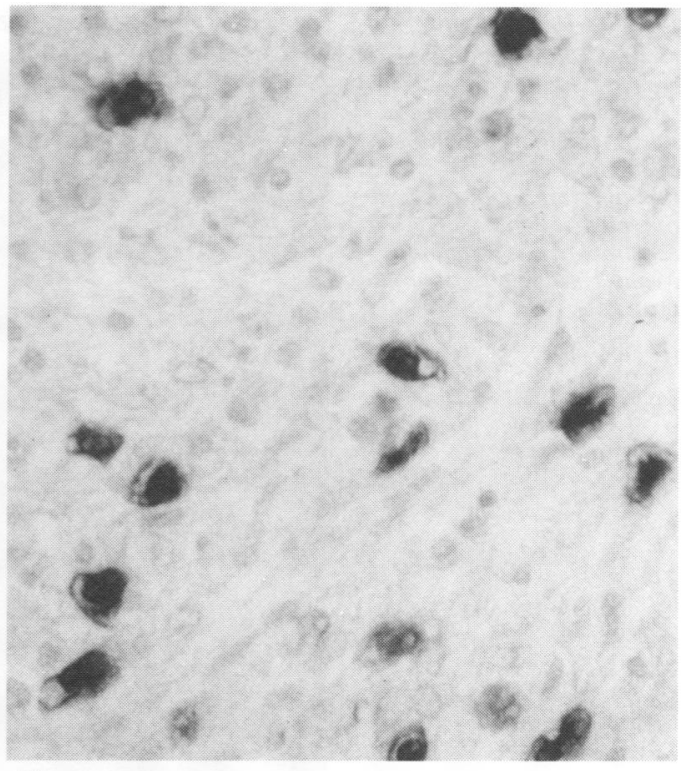

(B)

where p53 staining was mostly observed in paraimmunoblasts (fig 1A). The proportion of cases with positive cells varies according to the grade of malignancy $(50 \%$ for low grade, $64 \%$ for intermediate grade, and $79 \%$ for high grade lymphomas), histological subtype, and whether the tumours were of $\mathrm{B}$ or $\mathrm{T}$ cell origin ( $54 \%$ for B cell and $89 \%$ for T cell lymphomas-p < 0.01) (table).

The percentage of positive cells varied from occasional stained cells (less than $1 \%$ ) to $80 \%$ of the neoplastic cells. Cases with less than $1 \%$ positive cells were more common in low grade non-Hodgkin's lymphoma $(56 \%$ of positive low grade lymphomas, $36 \%$ of intermediate, and $18 \%$ of high grade lymphomas). The p53 LI of intermediate grade nonHodgkin's lymphoma was significantly higher than that of low grade NHL $(p<0.05$; Wilcoxon's test) (fig 1), but no significant difference was found between intermediate and high grade NHL (fig 2). A significant difference was also established between $B$ and

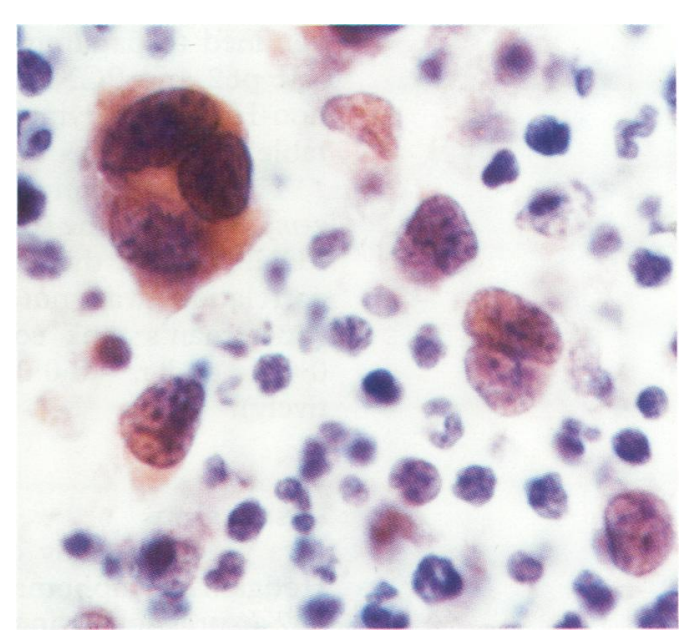

Figure 3 c-myc 1-9 E10 immunostaining in a high grade $T$ cell lymphoma showing nuclear and cytoplasmic staining of neoplastic cells. 
Figure 4 (A) PC10 immunostaining in a low grade (centroblasticcentrocytic) lymphoma showing scattered positive cells. (B) PC10 immunostaining in an intermediate grade (centroblastic) lymphoma. Many positive cells are seen.

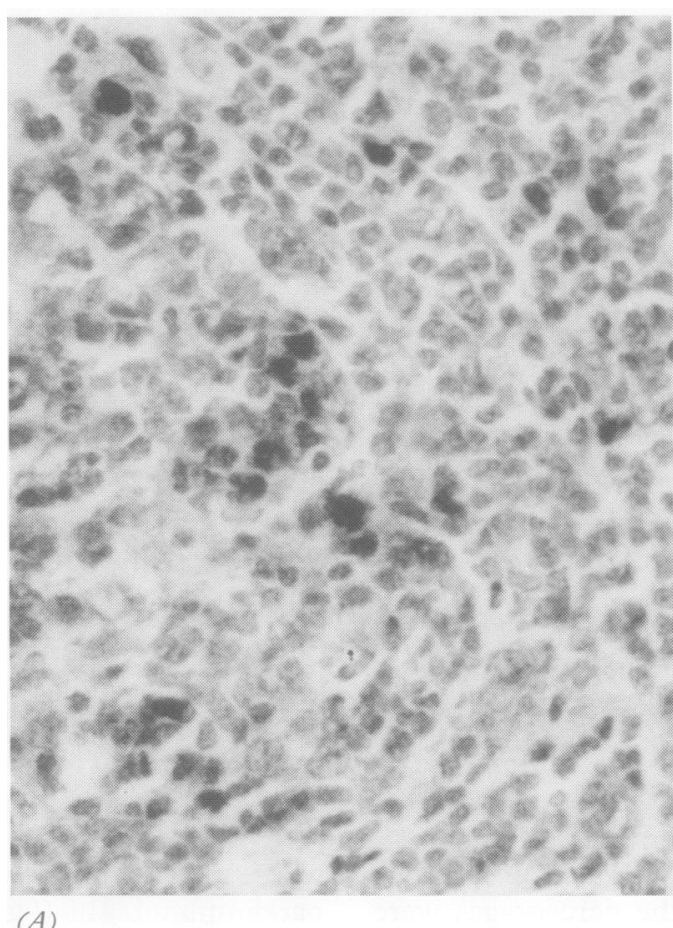

$T$ cell lymphomas, the latter displaying a higher LI ( $p<0.05$; Wilcoxon's test). This difference was not reproduced when the comparison was made within each grade of malignancy separately.

c-myc p62 immunoreactivity was identified in all cases ranging from $1 \%$ to $90 \%$ and was mainly nuclear, although some cytoplasmic staining was also observed (fig 3). Large cells with cleaved or non-cleaved nuclei, paraimmunoblasts, immunoblasts and lymphoblasts were stained more often. A varying number of non-lymphoid positive cells (histiocytes, reticulum, and endothelial cells) was also found.

Similarly, PCNA immunostaining was observed in all cases studied (fig 4). The staining pattern was of granular, diffuse, or mixed type in the nuclei, while in a small percentage of cases a weaker cytoplasmic staining was also seen. PC10 showed a predilection for blastic cells. This was best exemplified in low grade lymphomas, such as B CLL, where positive staining was mostly confined to paraimmunoblasts. The mean c$m y c$ p62 and PCNA LI for each subgroup of non-Hodgkin's lymphoma are shown in the table.

The p53 LI correlated positively with the c-myc LI on the one hand and with the PCNA LI on the other, although the rank correlation was not strong in either case (Spearman's rank correlation: $r_{s} 0.453, p<$ 0.001 , and $r_{s}=0.0 .0338, p<0.001$, respectively).

\section{Discussion}

In a previous study of a large series of nonHodgkin's lymphoma we showed that c-myc p62 expression is increased in most cases of non-Hodgkin's lymphoma. It was also shown that c-myc p62 and PCNA expression are both related to malignancy grade and that

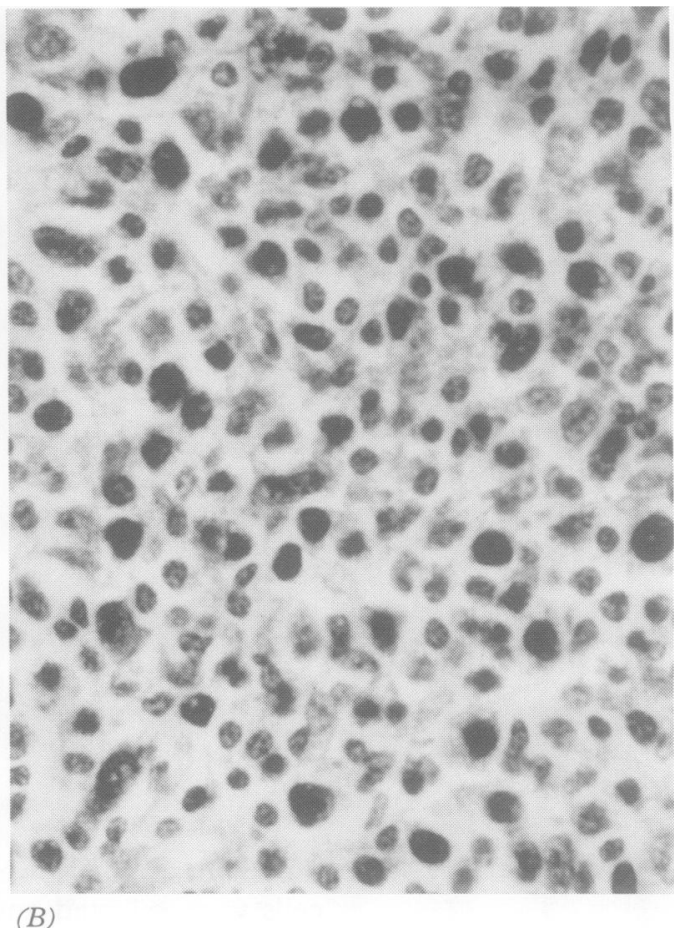

there is a moderate linear correlation between them $(r=0 \cdot 55) .^{32}$

In the present study we observed p53 immunoreactivity in $61 \%$ of cases of nonHodgkin's lymphoma. This percentage is similar to that reported by Villuendas et al ${ }^{18}$ and higher than that found by Soini et al, ${ }^{17}$ Pezzela et $a l^{19}$ and Said et al. ${ }^{20}$ Positive cells were identified in $50 \%$ of low grade lymphomas and in most intermediate $(69 \%)$ and high grade non-Hodgkin's lymphoma (79\%). These findings also agree with those of Villuendas et al. ${ }^{18}$ The LI was low $(<1 \%)$ in many cases, especially low grade malignancy, confirming previous reports. ${ }^{17-20}$ The LI was significantly lower in low grade lymphomas compared with intermediate and high grade non-Hodgkin's lymphoma, but no difference was found between the two latter groups. Positive cells in low grade lymphomas did not exceed $15 \%$; in higher grades more than one third of the cases had an LI greater than $15 \%$. This is similar to the finding of Villuendas et $a l^{18}$; in their series, however, the p53 LIs in low grade lymphomas were lower than $5 \%$. A difference was also established between $B$ cell and $T$ cell non-Hodgkin's lymphoma, but this may have been partly attributable to the higher proportion of intermediate and high grade cases in the $T$ cell group.

It has been suggested that greater p53 immunoreactivity in higher grade lymphomas and its predilection for the paraimmunoblasts in B CLL may reflect the progression of low to high grade in some cases. ${ }^{1718}$ This view is supported by data provided by sensitive molecular biology techniques ${ }^{21}$ by means of which p53 mutations were detected in B CLL and particularly in its stage of progression known as Richter's transformation. To explain the presence of sporadic positive cells in several cases it has been hypothesised by some authors ${ }^{17} 18$ that a non-mutational mech- 
anism could be responsible for the immunohistochemical detection of $\mathrm{p} 53$ protein in these instances. According to this theory, a high proliferation rate may result in detectable concentrations of wild p53 protein. ${ }^{1718}$ This is supported by the experimental finding of detectable amounts of wild p53 protein in phytohaemagglutinin stimulated, rapidly proliferating lymphocytes, ${ }^{42}$ and by the occurrence of sporadic positive cells in thymus and reactive lymphoid tissue. ${ }^{18}$

The correlation of p53 expression with the grade of malignancy may indicate that a high p53 LI has an adverse prognostic value. Indeed, Cabanillas et $a l^{43}$ have shown that patients with abnormalities in chromosome 17 , where the p53 gene is located, tend not to respond to chemotherapy and have a poor survival.

Published data show that $\mathrm{p} 53$ protein has a regulatory effect on the PCNA gene: the wild type protein selectively down-regulates PCNA mRNA and protein expression ${ }^{44}$ probably by inhibiting the function of the PCNA promoter ${ }^{45}$ whereas the mutant $\mathrm{p} 53$ seems to activate directly PCNA promoter. ${ }^{46}$ That a general activation of cellular growth may be the cause of PCNA promoter activation cannot be relevant. ${ }^{46}$ The weak positive correlation between p53 and PCNA expression in. non-Hodgkin's lymphoma established in our series may indicate that in most cases the p53 protein we detected immunohistochemically is of the mutant type. If the reverse were true a negative correlation would be expected. A similar correlation has been shown in primary lung carcinomas (Korkolopoulou et al, unpublished data) but not in central nervous system neoplasms. ${ }^{47}$

It has also been shown that p53 is a transcriptional modulator of $c-m y c$ expression: normal p53 inhibits the expression of $c-m y c^{23}$ and may initiate apoptosis by causing $G_{1} / S$ arrest in cells expressing c-myc. ${ }^{25}$ p53 mutations have been associated with $c-m y c$ gene deregulation in Burkitt's lymphomas and $\mathrm{L}_{3}$ acute lymphoblastic leukaemia, ${ }^{21} 48$ while a recent study indicates that in $\mathrm{B}$ cell lymphoid tumours the critical factor determining the involvement of mutant p53 is the maturation stage of transformed B lymphocytes, independently of $c-m y c$ deregulation. ${ }^{49}$ In this study we have shown a positive correlation between p53 and c-myc expression. According to the above data, this finding provides indirect evidence that in most cases of non-Hodgkin's lymphoma the p53 protein we detected immunohistochemically is not of the wild type.

To summarise, p53 immunoreactivity is present in most cases of non-Hodgkin's lymphoma and is related to the grade of malignancy and possibly to the $B$ or $T$ cell origin of the tumour. It is also correlated with the proliferation rate, as expressed by PCNA LI and c-myc p62 expression, indicating that the expression of these three cell cycle related genes is interrelated. The co-expression of c-myc and p53 may be linked to the proliferation rate or may suggest a role for these onco- genes in the pathogenesis of some cases of non-Hodgkin's lymphoma.

We thank Celltech (UK) Ltd for paying Jane Oates's salary and also Mrs Ruth Fry for her secretarial assistance.

1 Martinez J, Georgoff I, Martinez J, Levine AJ. Cellular localization and cell cycle regulation by a temperaturesensitive p53 protein. Genes Dev 1991;5:151-9.

2 Finaly CA, Hinds PW, Levine AJ. The p 53 protooncogene can act as a suppressor of transformation. Cell 1989;57:1083-93.

3 Eliyahu D, Michalevitz D, Eliyahu S, Pinhasi-Kimhi O, Oren $O$. Wild-type p53 can inhibit oncogene-mediated focus formation. Proc Natl Acad Sci USA 1989;86: 8763-7.

4 Baker SJ, Markowitz K, Fearon ER, Willson JKV, Vogelstein B. Suppression of human colorectal carcinoma

5 Diller L, Kassel J, Nelson CE, et al. p53 functions as a cell cycle control protein in osteosarcomas. Mol Cell Biol cycle control pro

6 Lane DP. p53, guardian of the genome. Nature 1992;358:15-16

7 Nigro JM, Baker SJ, Presinger AC, et al. Mutations in the p53 gene occur in diverse human tumour types. Nature 1989;342:705-8.

8 Harris AL. p53 - the commonest genetic abnormality in human cancer? f Clin Pathol 1990;162:5-6.

9 Levine AJ, Momand J, Finlay C. The p53 tumour suppressor gene. Nature 1991;351:453-6.

10 Rogel A, Popliker M, Webb CG, Oren M. p53 cellular tumor antigen: analysis of mRNA levels in normal adult tumor antigen: analysis of mRNA levels in normal adult 1985;5:2851-5.

11 Iggo R, Gatter K, Bartek J, Lane D, Harris AL. Increased expression of mutant forms of $\mathrm{p} 53$ oncogene in primary lung cancer. Lancet 1990;335:675-9.

12 Rodriguez NR, Rowan A, Smith MEF, et al. p53 mutation in colorectal cancer. Proc Natl Acad Sci USA 1990; 87:7555-9.

13 Scott N, Sagar P, Stewart J, Blair GE, Dixon MF, Quirke P. p53 in colorectal cancer: Clinicopathological correlation and prognostic significance. $B r \mathcal{F}$ Cancer 1991;63: 317-19.

14 Slingerland JM, Minden MD, Benchimol S. Mutation of the p53 gene in human acute myelogenous leukemia. the p53 gene in hum
Blood 1991;77:1500-7.

15 Prokocimer M, Shaklai M, Ben Bassat H, Walf D, Goldfinger N, Rotter V. Expression of p53 in human leukemia and lymphoma. Blood 1986;68:113-8.

16 Doglioni C, Pelosio P, Mombello A, Scarpa A, Chilosi M. Immunohistochemical evidence of abnormal expression of the antioncogene-encoded p53 phosphoprotein in Hodgkin's disease and CD $30+$ anaplastic lymphomas. Hematol Pathol 1991;5:67-73.

17 Soini Y, Paako P, Alavaikko M, Vahakangas K. p53 expression in lymphatic malignancies. 7 Clin Patho 1992;45:1011-14

18 Villuendas $\mathrm{R}$, Piris MA, Orradre $\mathrm{JL}$, et al. $\mathrm{p} 53$ protein expression in lymphomas and reactive lymphoid tissue. expression in lymphomas and

19 Pezzela F, Morrison H, Jones $M$, et al. Immunohistochemical detection of $\mathrm{p} 53$ and bc1-2 proteins in non-Hodgkin's lymphoma. Histopathology 1993;22: 39-44.

20 Said JW, Barrera R, Shintaku PI, Nakamura H, Koeffler PH. Immunohistochemical analysis of p53 expression in malignant lymphomas. Am $\mathcal{f}$ Pathol 1992;141:1343-8.

21 Gaidana G, Ballerini P, Gong JZ, et al. p53 mutations in human lymphoid malignancies: Association with Burkitt lymphoma and chronic lymphocytic leukemia. Proc Nat Acad Sci USA 1991;88:5413-17.

22 Gray D. Oncogenes and growth control in lymphoma. In Crocker J, ed. Cell proliferation in lymphomas. Oxford: Crocker J, ed. Cell proliferation in lymphomas.
Blackwell Scientific Publications, 1993:62-86.

23 Thompson CB, Challoner PB, Newman PE, et al. Levels of $c-m y c$ oncogene mRNA are invariant throughout the cell cycle. Nature 1985;314:363-70.

24 Stewart TA, Belve AR, Leder P. Transcription and promoter usage of the myc gene in normal comatic and spermatogenic cells. Science 1984;226:707-10.

25 Wyllie AH. Apoptosis. Br f Cancer 1993;67:205-8. specific regulation of the c-myc gene by lymphocyte mitogens and platelet derived growth factor. Cell 1983; 35:603-10.

27 Evan GI, Hancock DC. Studies on the interaction of the human c-myc protein with cell nuclei: P62 c-myc as a

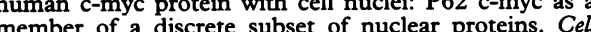
member of a discr

28 Jack AS, Kerr IB, Evan G, Lee FD. The distribution of the c-myc oncogene product in malignant lymphomas the c-myc oncogene product in malignant lymphomas and various normal tissues as demonstra

29 Waldman TA, Korsmeyer SJ, Backshi A, Arnold A Kirsch I. Molecular genetic analysis of human lymphoid 
neoplasms immunoglobulin genes and the c-myc oncogene (NIH Conference). Ann Int Med 1985;102 497-510.

30 Mitani S, Sygawara I, Shiku H, Mori S. Expression of cmyc oncogene product and ras-family oncogene product in various human malignant lymphomas defined by immunohistochemical techniques. Cancer 1988;62. 2085-93.

31 Kittas C, Korkolopoulou P, Pangalis G, Boussiotis VA Tsenga A, Spandidos D. Expression of c-myc p62 proTsenga A, Spandidos D. Expression of c-myc p62 protein in non- $1990 ; 1: 241-7$.

32 Korkolopoulou P, Patsouris E, Pangalis G, et al. A comparative assessment of proliferating cell nuclea antigen (PCNA), c-myc p62 and nucleolar organize region (NOR) staining in non-Hodgkin's lymphomas. A histochemical and immunohistochemical study of 100 cases. Hum Pathol 1993;24:371-7.

33 Wynford-Thomas D. Oncogenes and anti-oncogenes; the molecular basis of tumour behaviour. F Pathol 1991, 165:187-201.

34 Almendral JM, Huebsch D, Blundell AP, MacdonaldBravo $\mathrm{H}$, Bravo $\mathrm{R}$. Cloning and sequence of the human nuclear protein cyclin homology with DNA-binding proteins. Proc Natl Acad Sci USA 1987;84:1575-9.

35 Stillman B. Initiation of eukaryotic DNA replication in vitro. Annu Rev Cell Biol 1989;5:197-245.

36 Takasaki Y, Deng JS, Tan EM. A nuclear antigen associated with cell proliferation and blast transformation: It distribution in synchronized cells. $\mathcal{F}$ Exp Med 1981 154:1899-909.

37 Celis JE, Celis A. Cell cycle dependent variations in the distribution of the nuclear protein cyclin/proliferating cell nuclear antigen in cultured cells: subdivision of the $S$ phase. Proc Natl Acad Sci USA 1985;82:3262-6.

38 Woods AL, Hall PA, Shepherd NA, et al. Proliferating cell nuclear antigen PCNA immunostaining in primary gastrointestinal lymphomas and its relationship to histologic grade, $S+G 2+M$ phase fraction (flow cytometric analysis) and prognosis. Histopathology 1991; 18:21-7.
39 Dervan PA, Macgee HM, Buckley C, et al. Proliferating cell nuclear antigen counts in formalin-fixed paraffinembedded tissue correlate with $\mathrm{Ki}-67$ in fresh tissue. Am $\mathcal{f}$ Clin Pathol 1992;97(Suppl I):521-8.

40 National Cancer Institute. Sponsored study of classification of non-Hodgkin's lymphomas: summary and description of a working formulation for clinical usage. Cancer 1982;49:2112-35.

41 Hall PA, Levison DA, Woods AL, et al. Proliferating cell nuclear antigen (PCNA) immunolocalisation in paraffin sections: An index of cell proliferation with evidence of sections: An index of cell proliferation with evidence of 1990;162:285-94.

42 Mercer WE, Baserga R. Expression of the p53 protein during the cell cycle of human peripheral blood lymphocytes. Exp Cell Res 1985;160:31-46.

43 Cabanillas F, Pathak S, Grant G, et al. Refractoriness to chemotherapy and poor survival related to abnormalitie of chromosomes 17 and 7 in lymphoma. $A m \mathcal{F ~ M e d}$ 1989;87:167-72.

44 Mercer WE, Shields MT, Lin D, Appela E, Ullrich SJ. Growth suppression induced by wild-type $\mathrm{p} 53$ protein is accompanied by selective down-regulation of proliferating cell nuclear antigen expression. Proc Natl Acad Sci ing cell nuclear antigen

45 Suler MA, Martin DW, Deb S. Inhibition of viral and cellular promoters by human wild-type p53. $f$ Virol 1992;66:4757-62

46 Deb S, Jackson CT, Subler MA, Martin DW. Modulation of cellular and viral promoters by mutant human $\mathrm{p} 53$ proteins found in tumor cells. F Virol 1992;66:6164-70.

47 Barbareschi M, Iuzziolino $\mathrm{P}$, Pennella $\mathrm{A}$, et al. $\mathrm{p} 53$ protein expression in central nervous system neoplasms. $f$ Clin Pathol 1992;45:583-6.

48 Gutierrez MI, Magrath IT, Huppi K, Siwarski D, Bhatia $\mathrm{K}$. Association of p53 mutations in lymphoid tumors with a deregulated c-myc gene. Blood 1991;78(Suppl 1): with a
$324 a$.

49 Gutierrez MI, Bhatia K, Siwarski D, et al. Infrequent p53 mutation in mouse tumors with deregulated myc Cancer Res 1992;52:1032-5. 